\title{
Alternative tourism: a pathway for sustainability in the Cabo Pulmo National Park, Baja California Sur, Mexico: a SWOT analysis
}

\author{
A. Ivanova, R. Ibañez, A. Gamez \& M. Angeles \\ Autonomous University of Southern Baja California, USA
}

\begin{abstract}
Many studies highlight alternative tourism as a path for sustainable local development in marine protected areas. However appropriate tools to measure the sustainability of tourism development must be implemented. The case of our study is the Cabo Pulmo National Park, located in Baja California Sur, Mexico. The methodology applied is the IUCN sustainability assessment and an analysis of Strengths, Opportunities, Weaknesses and Threats (SWOT), based on a comprehensive review of statistics and documents, and on an opinion survey of the main stakeholders and key players. The analysis clearly shows that there are elements for sustainability based on alternative tourism. Nevertheless, to achieve this desirable model of development some constraints need to be overcome. Based on our analysis, we underscore the main points which should be taken into account in the process of policy making. Albeit oriented to the needs of a specific community, we think that these considerations should be of benefit in constructing sustainable development projects elsewhere, in similar small coastal communities with alternative tourism activities.
\end{abstract}

Keywords: alternative tourism, sustainable development, sustainability assessment, marine protected area, small coastal community, SWOT analysis, Cabo Pulmo, Mexico.

\section{Introduction}

In response to a growing recognition of the need for conservation efforts resulting from the degradation of ocean systems, marine protected areas (MPAs) 
are being established worldwide. If designed correctly and managed well, MPAs have an important role to play in the protection of ecosystems and, in some cases, enhancing or restoring the productive potential of coastal and marine fisheries. However, it is recognized that MPAs are not the only solution for coastal and marine problems. For example, when MPAs are used in conjunction with other management tools, such as the integrated planning of economic activities and sustainability management, they can provide a solid offer the cornerstone for a strategy for sustainable development [3, 4].

When appropriately placed and well-managed, MPAs contribute to:

- Conserving biological diversity and associated ecosystems.

- $\quad$ Providing focal points for educating the public about marine ecosystems and human impacts upon them.

- Nature-based recreation and tourism.

- Providing undisturbed control or reference sites that serve as baselines for scientific research and for designing and evaluating other areas.

- Sharing costs and benefits among local communities, the private sector, regional and national governments, and other stakeholders [18].

- Reducing poverty and increasing the quality of life in surrounding communities by development of sustainable tourism $[12,19]$.

The aim of this paper is to evaluate the sustainability of the alternative tourism activities performed by the community of the Cabo Pulmo National Park MPA, Mexico.

\section{Case study}

The Cabo Pulmo National Park is a Marine Protected Area in the Municipality Los Cabos of the State of Baja California Sur Mexico, located between $23^{\circ} 22^{\prime}$ $30^{\prime \prime}$ and $23^{\circ} 30^{\prime} 00^{\prime \prime}$ North $109^{\circ} 28^{\prime} 03^{\prime \prime}$ and $109^{\circ} 28^{\prime} 00^{\prime \prime}$ West, in the Gulf of California. It is famous because it has the largest coral reef on the Pacific coast of the Americas, and is home to many species from the bio-geographical provinces of Panama, as well some species from Indo-Pacific areas [17, 18].

As IUCN (2008) states: "Large natural or near natural areas set aside to protect large scale ecological processes, along with the complement of species and ecosystems characteristic of the area, help to provide a foundation for environmentally and culturally compatible spiritual, scientific, educational, recreational and visitor opportunities." In the Cabo Pulmo area, several small community enterprises are doing sustainable tourism, such as diving, snorkelling and kayaking [7]. The local inhabitants had an active role in the establishment of the MPA and are conscientious about the conservation of the environment and unique natural resources of the site [8. 16]. However in this context appropriate tools to measure the sustainability of tourism development must be implemented. 


\section{Methods}

First, we use as research tool a sustainability assessment based on the IUCN indicators combined with the indicators developed by UNWTO for tourism activities and adapted to a small coastal community. The field data are obtained from survey and in-depth interviews with government officials, local residents and academics.

Second, the results are presented in the form of a barometer of sustainability which enables users to obtain clear messages, gain an overview of wellbeing and sustainability, and show where performance is especially weak or strong. The barometer of sustainability is a tool for combining indicators and displaying the results. It is designed to measure human and ecosystem wellbeing together without submerging one into the other. It has two axes, one for human wellbeing, the other for ecosystem wellbeing. The axis with the lower score overrides the other axis. Each axis is divided into five bands for greater flexibility and control of the scale.

Figures 1 and 2 show examples of the required information for each case.

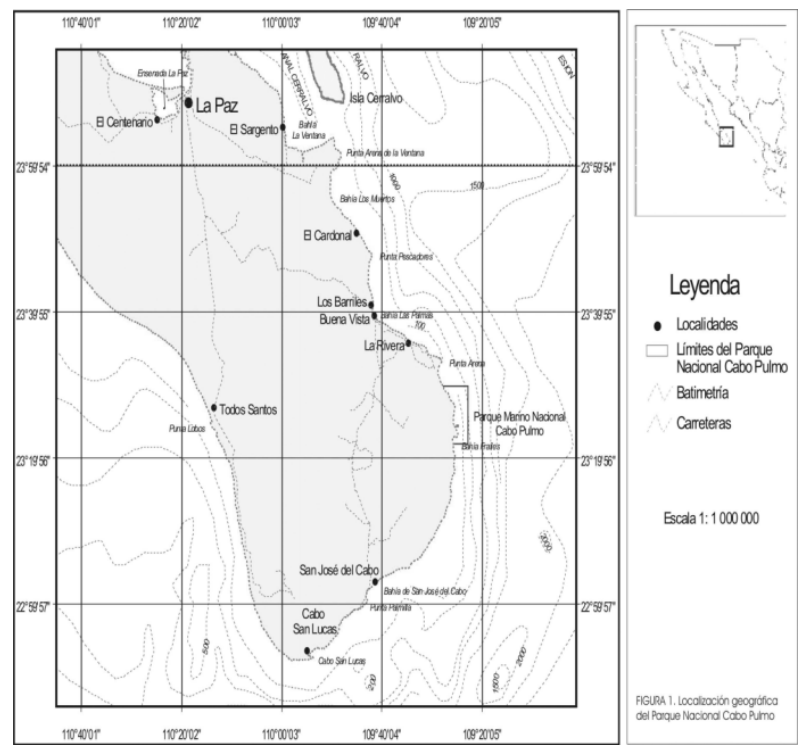

Figure 1: $\quad$ Location of Cabo Pulmo National Park, Mexico.

Third, based on the results of the sustainability assessment, the Strengths, Weaknesses, Opportunities and Threats (SWOT) analysis is used to identify problems related to the sustainability. As Talancón [15] suggests, environmental, economic, social, cultural and legal factors are examined. 


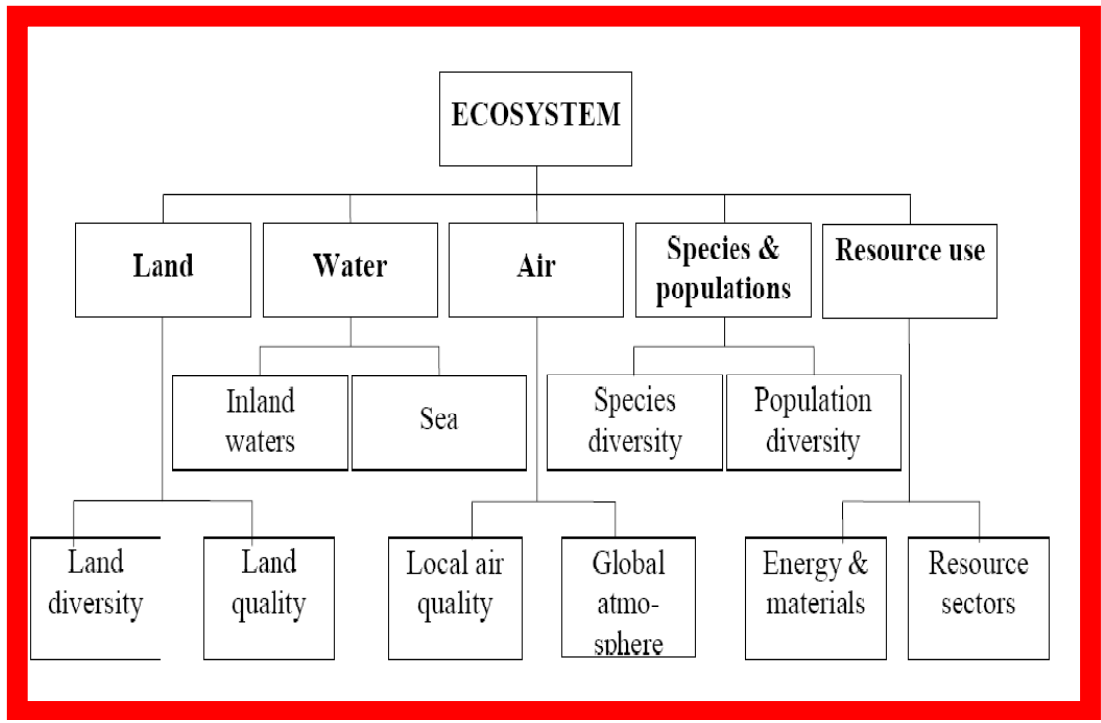

Figure 2: $\quad$ Indicators for ecosystem wellbeing, IUCN (2001).

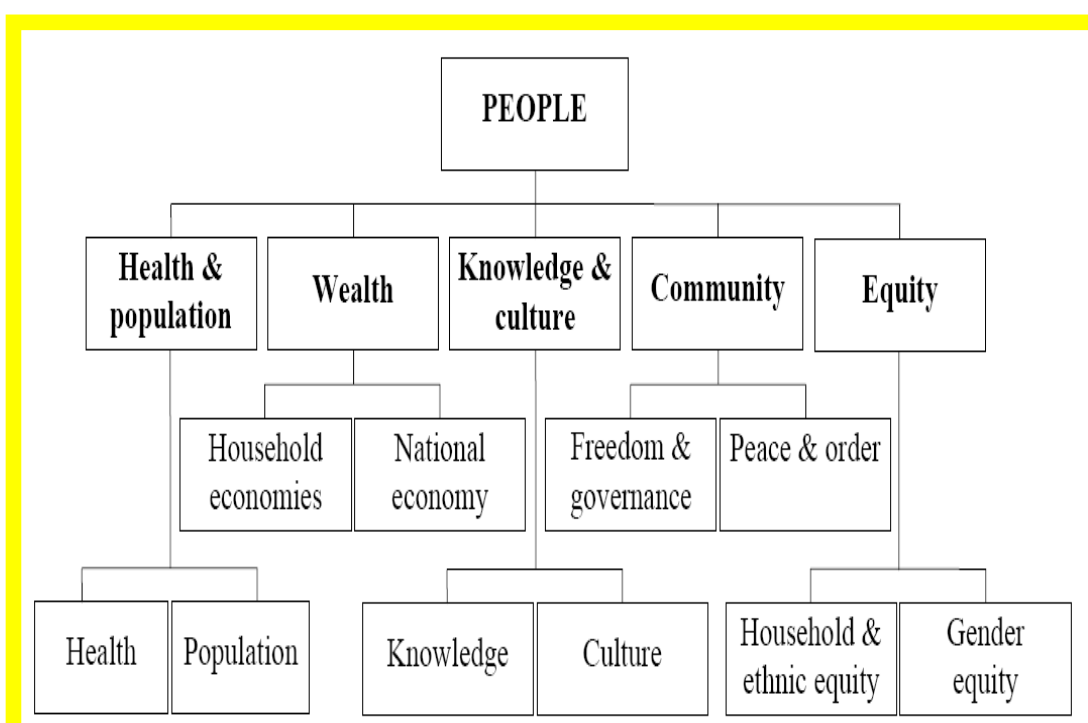

Figure 3: Indicators for human wellbeing, IUCN (2001). 


\section{Results}

Results of the process as applied to the Cabo Pulmo National Park MPA are shown below in graph form. It should be noted that overall Ecosystem Wellbeing (EW) earns very high marks, 85 out of a possible 100, indicating a sustainable ecosystem. On the other hand, Human Wellbeing (HW) stands at only 58, a middling mark, implying below "almost sustainable" condition. Thanks to the EW and HW combination, the Cabo Pulmo area is ranked as a medium sustainable development region.

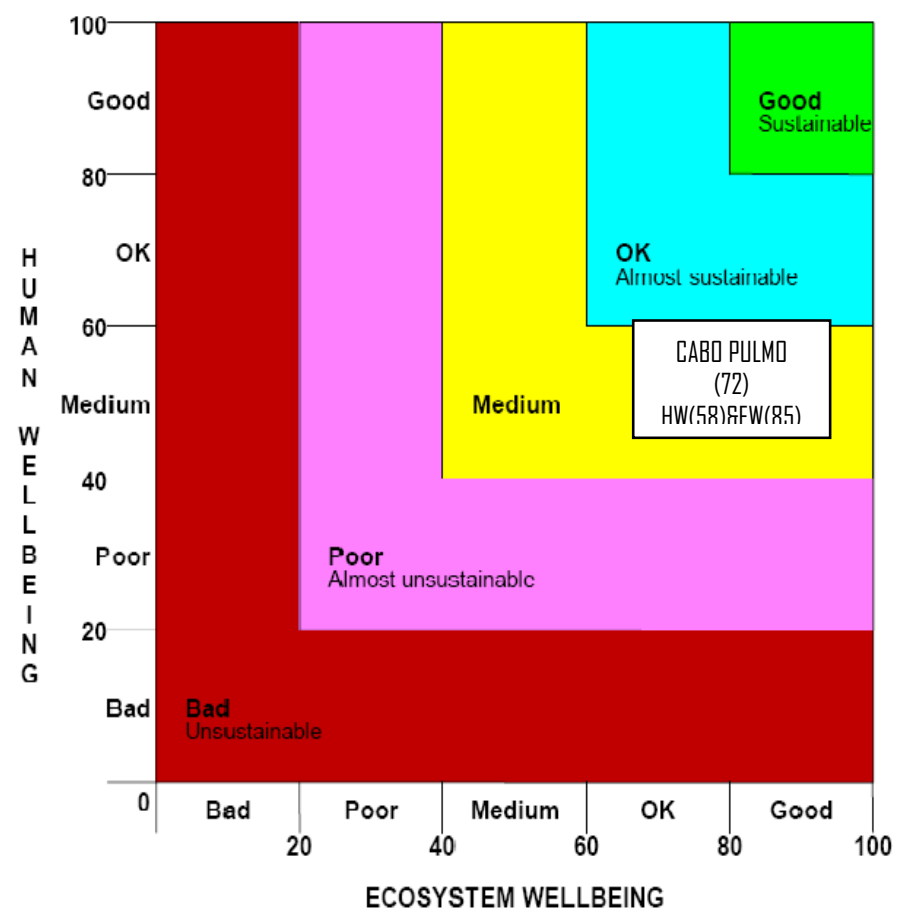

Figure 4: Position of Cabo Pulmo on the barometer of sustainability (as result of our study).

The results just presented prompted the SWOT analysis mentioned above, as shown in Tables 1 and 2. 
Table 1: $\quad$ Internal analysis (strengths and weaknesses).

\begin{tabular}{|c|c|c|}
\hline Factors & Strengths & Weaknesses \\
\hline Environmental & $\begin{array}{l}\text { - Natural landscape and } \\
\text { ecosystems; sea, beach, endemic } \\
\text { flara and fauna; spart fishing. } \\
\text { - Coral reefs unique in the Pacific } \\
\text { [I6, I7] } \\
\text { - National Park (Marine Protected } \\
\text { Area). } \\
\text { - Strang enviranmental NGDs. }\end{array}$ & $\begin{array}{l}\text { - Deficient waste management. } \\
\text { - The carrying capacity is not } \\
\text { defined. }\end{array}$ \\
\hline $\begin{array}{l}\text { Economic and } \\
\text { Financial. }\end{array}$ & $\begin{array}{l}\text { - Viability of a development pattern } \\
\text { based an the alternative tourism } \\
\text { [G]. } \\
\text { - The local community obtains high } \\
\text { incomes performing alternative } \\
\text { tourism services. } \\
\text { - The site is attractive to visitars } \\
\text { with high and medium income. } \\
\text { - The local SMEs are advertising } \\
\text { their services by Internet. }\end{array}$ & $\begin{array}{l}\text { - Insufficient infrastructure: } \\
\text { hostels, roads. } \\
\text { - Lack of maintenance of the } \\
\text { existing roads. } \\
\text { - Difficult access to drinking } \\
\text { water. } \\
\text { - Difficulties for the locals to } \\
\text { access financing } \\
\text { (insufficient information } \\
\text { on the available finance } \\
\text { resources, high } \\
\text { collaterals) [9]. }\end{array}$ \\
\hline $\begin{array}{l}\text { Social and } \\
\text { Cultural }\end{array}$ & $\begin{array}{l}\text { - Hospitality of local inhabitants. } \\
\text { - Human capacities building (a high } \\
\text { percentage of the local young } \\
\text { people studying alternative } \\
\text { tourism). } \\
\text { - Community members are part of } \\
\text { environmental NGDs (protecting } \\
\text { the MPA) } \\
\text { - High community consciousness on } \\
\text { conservation and natural } \\
\text { resources protection } \\
\text { - Programs on enviranmental } \\
\text { education implemented in the } \\
\text { community. }\end{array}$ & $\begin{array}{l}\text { - There are no primary schouls. } \\
\text { - There are no medical services. } \\
\text { - The local entrepreneurs need } \\
\text { advice on business } \\
\text { management and } \\
\text { financing. } \\
\text { - Lack of cultural and spart } \\
\text { activities for the } \\
\text { community. } \\
\text { - Local traditions are not } \\
\text { consalidated. } \\
\text { - Insufficient courdination } \\
\text { between the public and } \\
\text { business sector. } \\
\text { - Centralized patriarchal } \\
\text { decisions on the land use } \\
\text { within the families. } \\
\text { - Land speculation. }\end{array}$ \\
\hline Legal & $\begin{array}{l}\text { - } \quad \text { Laws and regulations on } \\
\text { enviranmental protection. } \\
\text { - } \quad \text { Program on management of the } \\
\text { NP [5] }\end{array}$ & $\begin{array}{l}\text { - Lack of land property } \\
\text { definition. } \\
\text { - Difficulties far enviranmental } \\
\text { laws compliance. } \\
\end{array}$ \\
\hline
\end{tabular}


Table 2: $\quad$ External analysis (opportunities and threats).

\begin{tabular}{|c|c|c|}
\hline Factors & Dpportunities & Threats \\
\hline Environmental & $\begin{array}{l}\text { - Clean and attractive } \\
\text { environment, competitive on } \\
\text { world level. } \\
\text { - Unique coral reef in the } \\
\text { Pacific. }\end{array}$ & $\begin{array}{l}\text { - Growing supply of alternative } \\
\text { tourism services in Central } \\
\text { American and Asia Pacific } \\
\text { destinations } \\
\text { - Possible damages to the } \\
\text { enviranment due to } \\
\text { insufficient management and } \\
\text { no specified natural carrying } \\
\text { capacity. }\end{array}$ \\
\hline $\begin{array}{l}\text { Economic and } \\
\text { Financial }\end{array}$ & 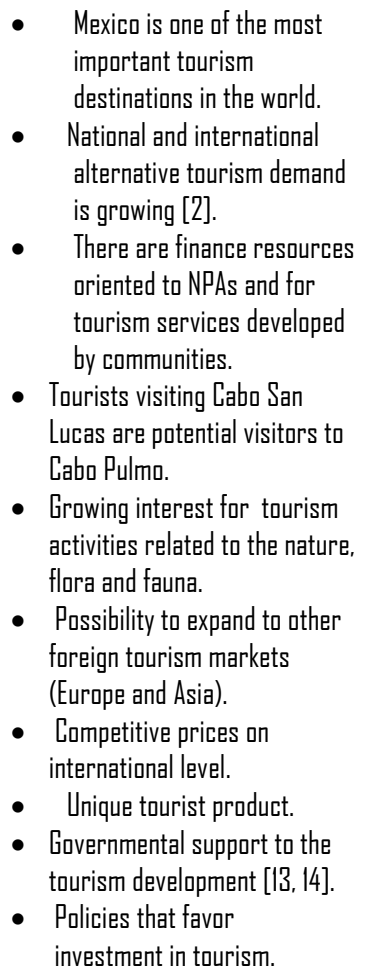 & $\begin{array}{l}\text { - } \quad \text { Lack of adequate schemes to } \\
\text { design, develop, and } \\
\text { promote the region's } \\
\text { tourism products. } \\
\text { - } \quad \text { Increasing demand far } \\
\text { quality services. } \\
\text { - } \quad \text { Difficulties in the financing } \\
\text { of alternative tourism } \\
\text { projects. } \\
\text { - Competition from ather } \\
\text { touristic destinations with } \\
\text { more infrastructure. } \\
\text { Neighboring communities } \\
\text { that offer greater facilities } \\
\text { to tourists. } \\
\text { - Existence of a massive } \\
\text { second-residence and } \\
\text { hotel, golf course, and } \\
\text { shopping mall project, to } \\
\text { be located adjacent to the } \\
\text { area. }\end{array}$ \\
\hline
\end{tabular}


Table 2: $\quad$ Continued.

\begin{tabular}{|l|l|l|}
\hline Factors & Dpportunities & Threats \\
\hline
\end{tabular}

\begin{tabular}{|c|c|c|}
\hline Sacial & $\begin{array}{ll}\text { - } & \text { Empowerment of the local } \\
\text { community for decision- } \\
\text { making and participation in } \\
\text { the development } \\
\text { - Higher incomes for local } \\
\text { families } \\
\text { - Better infrastructure } \\
\text { (roads, schools, clinics, } \\
\text { etc) }\end{array}$ & $\begin{array}{ll}- & \text { Possible loss of local } \\
\text { - identity and values } \\
\text { - } \\
\text { Insufficient participation of } \\
\text { local community in the } \\
\text { incomes generated by } \\
\text { tourism activities. }\end{array}$ \\
\hline Legal & $\begin{array}{l}\text { - Laws fastering tourism } \\
\text { development in Mexica and } \\
\text { in the state of Baja } \\
\text { Califarnia Sur } \\
\text { - } \quad \text { Laws on enviranmental } \\
\text { pratection and an MPAs }\end{array}$ & $\begin{array}{ll}\text { - } & \text { Centralized development } \\
\text { policies. } \\
\text { - } \quad \text { Lack of legal mechanisms } \\
\text { to guarantee the local } \\
\text { participation in the } \\
\text { development. }\end{array}$ \\
\hline
\end{tabular}

\section{Discussion and recommendations}

The analysis clearly shows that there are elements for the sustainable development based on alternative tourism in the Cabo Pulmo National Park. Nevertheless, to achieve this desirable model of development some constraints need to be overcome [8]. Based on the previous analysis, we next underscore the main points which, in our opinion, should be taken into account in the process of policy making. Albeit oriented to the needs of a specific community, we think that these considerations should be of benefit in constructing sustainable development projects elsewhere, in similar small coastal communities with alternative tourism activities. Our recommendations are as follows.

i. Create a transparent regime and guarantees on the land.

The lack of security on the property of the land is a constraint for community members in developing infrastructure and real estate for tourism activities, even when governmental support is offered.

ii. Development of basic infrastructure necessary to offer better tourism facilities and service, while at the same time creating better living conditions for the community.

We do not suggest big hotels or buildings, but small environmentally friendly hostels owned by locals. Although finance will be required, we think that this would be a necessary an important action, because at present most of the existing facilities are owned by foreigners, which brings little benefit to the locals. Also, roads must be in good shape, so as to guarantee the continuous and safe access to the site. 
iii. Basic services.

The most important are the medical attention and the availability of drinking water. The implementation of these services is not only important for the visitors (it would allow them the possibility of extending their stay in the National Park); it is also clear that raising to social sustainability indicators is of vital importance for the local people.

\section{iv. Education and culture.}

A primary school is also necessary for the local children, which today must attend school in a nearby locality. It is also necessary to create recreation spaces for community members. The joint cultural experiences will contribute to the family and social cohesion.

\section{v. Environmental education}

It is important to introduce into the community more programs on environmental education, both for tourist and community members. It is an important to involve the community in waste recycling programs and natural park management and conservation. As well, visitors must not only be informed about the characteristics and value of the local resources, but also how to interact with the nature in the "Leave No Trace" manner, and without causing damage.

\section{vi. Capacity building in business management and access to finance resources.}

To have more success in their small businesses many locals would appreciate professional advice and assistance. Most local entrepreneurs and community organizations interested in the alternative tourism market do not have the necessary skill sets to operate successful tourism establishments. Assistance could be provided by government agencies or by higher learning institutions in the state of Baja California Sur. Thus the creation of human capital would be fostered, with positive impacts on the competitiveness of the site.

\section{vii. Create mechanisms oriented to foster the local management of the tourism.}

This study shows that the Cabo Pulmo National Park development is based on the convergence of groups of factors. The first is exogenous, based on central government investments, e.g. the creation of the MPA. The second is based on endogenous factor, in particular the presence of a small cultural and social system whose intrinsic relationships are able to generate productive efficiency and sustainability.

\section{viii. Foster research on natural resources management.}

In this context the priority is to define the site's carrying capacity and avoid endangering local natural resources, with the coral reef as a priority. The conservation and management must be carried out of sites with respect for a site's carrying capacity. This will require that the tourism sector cooperate with and work under the guidance of professional conservators. It is also important to continue to develop methods and indicators that enable us to evaluate the sustainability of the local development. 


\section{Final remarks}

Alternative tourism practice within marine protected areas is a long-term commitment. But while it is important to think long-term, it is also necessary to set realistic short and mid-term goals.

It is important for marine protected area planners to develop incentive measures that will influence decision-making processes within society. It is necessary to create inducements to incite or motivate government, local people, and international organizations to conserve biological and cultural diversity. The existing legislation and economic policies need to be reviewed in order to identify and promote incentives for the conservation and sustainable use of the resources, involving directly the local community.

Based on empirical research carried out in Cabo Pulmo National Park we can state that there is a great potential for a sustainable and community based development based on alternative tourism. The main strengths in this context are the natural landscape and ecosystems; sea, beach, endemic flora and fauna; and the coral reefs unique in the Pacific. The local community obtains high incomes performing alternative tourism services. Community members are part of environmental NGOs, and present high consciousness on conservation and natural resources protection

However our research shows also some weaknesses that must be addressed to reinforce the critical success factors for sustainability in Cabo Pulmo National Park. The list of suggestions for policy makers provided in part 4 - if applied could turn this potential into reality in a relatively short time. Finally, it is important to highlight that the success of the sustainable tourism development depends on the collaboration of all the stakeholders, government, business, and, in first place, the community members that must become the principal agents of local development.

\section{References}

[1] Borrie, W., McCool, S., Stankey, K. \& Engeldrum, B., Protected Area Planning Principles and Strategies. Ecotourism: A guide for Planners and Managers The Ecotourism Society 2: 133-154, 1998.

[2] Bringas N. \& Ojeda L., El ecoturismo: ¿una nueva modalidad del turismo de masas, Economía, Sociedad y Territorio, Vol. II, núm. 7, 2000.

[3] Cicin-Sain, B. \& Belfiore, S., Linking marine protected areas to integrated coastal and ocean management: A review of theory and practice. Ocean \& Coastal Management 48: 19, 2005.

[4] Christie, P. \&White, A. \& Deguit E., Starting point or solution? Community-based marine protected areas in the Philippines. Journal of Environmental Management 00: 14, 2002.

[5] Comisión Nacional de Áreas Naturales Protegidas (CONANP). Programa de Conservación y Manejo: Parque Nacional Cabo Pulmo, México, D.F, 2006. 
[6] Gámez, A., Turismo y Sustentabilidad en Cabo Pulmo, SDSU \& UABCS \& CONACYT, México, D. F., 2008.

[7] Ibáñez, R., Turismo alternativo, Gestión y Desarrollo Local. El Caso de Cabo Pulmo, B.C.S, Tesis para obtener el grado de Maestra en Ciencias, UABCS, La Paz, México, 2007.

[8] Ibáñez, R. \& Gámez, A. \& Ivanova A., Análisis ambiental de la actividad turística en Cabo Pulmo. Turismo y Sustentabilidad en Cabo Pulmo, Ed. A.E. Gamez, SDSU \& UABCS \& CONACYT, México, D. F., pp.191-222, 2008.

[9] Ivanova, A. \& Nikolov, D., Fuentes de financiamiento para actividades sustentables en Cabo Pulmo. Turismo y Sustentabilidad en Cabo Pulmo, Ed.A E. Gamez, SDSU \& UABCS \& CONACYT, México, D. F., pp. 99132, 2008.

[10] IUCN. Resource Kit for Sustainability Assessment, Gland. Switzerland \& Cambridge, UK, 2001.

[11] IUCN. Establishing Resilient Marine Protected Areas Network- Making It Happen. Washington, D.C., US, 2008.

[12] Santiago Jiménez, M. E., La Participación Local en Procesos Productivos Sustentables: Estudio de Caso en Tres Comunidades de la Costa de Oaxaca, ED. Instituto Tecnológico de Oaxaca. México, D.F., 2004.

[13] SECTUR, Programa Nacional de Turismo: 2001-2006, México, D.F., 2001.

[14] SECTUR, Programa Nacional de Turismo: 2006-2011, México, D.F., 2006.

[15] Ponce Talancón, H. La matriz FODA: una alternativa para realizar diagnósticos $y$ determinar estrategias de intervención en las organizaciones productivas y sociales, Instituto Politécnico Nacional. México, D.F., 2006.

[16] Núñez, E., El papel de los arrecifes de coral en el desarrollo económico y social de los municipios de Los Cabos, Baja California Sur, Puerto Vallarta, Jalisco y Santa María Huatulco, Oaxaca, Tesis de maestría. Colegio de la Frontera Norte. Tijuana, México, 2005. [http://public. jubiloweb.com/somac/congreso/I.\%20Ecología\%20No\%20Corales/Orales/ Alvarez-Filip.htm](01/12/08)

[17] Reyes Bonilla, H. \& Rodríguez Martínez, R. E., Estado actual de los corales arrecífales en México: especies en riesgo, Universidad Autónoma de Baja California Sur y Universidad Nacional Autónoma de México.

Instituto de Ciencias del Mar y Limonología. Unidad Académica Puerto Morelos. Moles, México, 2005. [http://www.jornada.unam.mx/ 2005/01/31/eco-e.html] (14/05/08).

[18] Sala E., Aburto-Oropeza O., Paredes G., Parra I., Barrera J.C., \& Dayton P.K., A general model for designing networks of marine reserves. Science 298: 1991-1993, 2002.

[19] Wearing, S. \& Neil J., Ecoturismo, impacto, tendencias y posibilidades, Editorial Síntesis Madrid, España, 1999. 